\title{
Tinjauan Yuridis Hubungan Hukum Dan Penerapan Asas Proporsionalitas Perjanjian Antara PT. Go-jek Indonesia Dengan Pelaku Usaha F\&B
}

\author{
Adinda Pirmansyah ${ }^{1}$ dan Imanudin Affandi $^{2}$ \\ ${ }^{1,2}$ Fakultas Hukum, Universitas Singaperbangsa Karawang \\ Corresponding author. Email: 1710631010023@student.unsika.ac.id
}

Naskah diterima: 01-01-2021 revisi: 17-11-2021; disetujui: 30-11-2021

DOI: https://doi.org/10.46257/jrh.v25i2.188

\begin{abstract}
Abstrak
Kemajuan teknologi yang semakin pesat mengakibatkan perubahan gaya hidup manusia, perkembangan teknologi ini kemudian dimanfaatkan untuk mengembangkan inofasi khususnya pada bidang bisnis seperti $e$-commerce. Go-jek merupakan perusahaan teknologi yang dapat melayani pemesanan ojek daring hingga segala jenis transaksi dan jasa pengantaran terutama pengantaran makanan. Hal ini dimanfaatkan oleh pelaku usaha makanan dan minuman (F\&B), pelaku usaha tersebut menjalin kerjasama dengan Go-jek untuk mengembangkan usahanya secara digital melalui perjanjian yang telah dibuat sebelumnnya oleh Go-jek. Permasalahan yang dikaji yaitu mengenai hubungan hukum apa yang timbul antara Go-jek dengan pelaku usaha dan bagaimana pembagian hak dan kewajiban para pihak dikaitkan dengan asas proporsionalitas. Tujuan penelitian adalah untuk mengkaji hubungan hukum yang terjalin antara Go-jek dengan pelaku usaha F\&B, serta mengkaji pembagian hak dan kewajiban antara Go-jek dengan pelaku usaha F\&B. Metode penelitian yang digunakan yaitu metode penelitian berupa metode penelitian yuridis normatif serta telaah aturan perundang undangan. Berdasarkan hasil penelitian dapat disimpulkan bahwa Go-jek telah menentukan isi perjanjian, bawah perjanjian dilakukan secara digital, dan dapat disetujui secara digital pula, bahwa setelah pelaku usaha menyetujui perjanjian maka pelaku usaha secara otomatis menjadi mitra, bahwa Go-jek berhak menggunakan Hak kekayaan intelektual milik mitra usaha mengenai tampilan, selain itu Go-jek berhak untuk menentukan SOP yang dapat ditambah atau dikurangi dari waktu ke waktu,dan pelaku usaha berhak mengakses layanan dan sebagai gantinya membayar sejumlah keuntungan sebesar $20 \%$ pada stiap transaksi yang terjadi. Hubungan hukum yang timbul adalah perjanjian kemitraan, dan bahwa perjanjan antara Go-jek dengan pelaku usaha tidak sepenuhnya memenuhi asas proporsionalitas.
\end{abstract}

Kata kunci: e-commerce, perjanjian, kemitraan, asas proporsionalitas.

\section{Juridical Review of Legal Relations and The Implementation of The Proporsionality of Agreements Between PT. Go-jek Indonesia with $F \& B$ Enterprises}




\begin{abstract}
Increasingly rapid technological advances have resulted in changes in human lifestyles, these technological developments are then used to develop innovation, especially in the business field such as e-commerce. Go-Jek is a technology company that can serve online motorcycle taxi orders to all types of transactions and delivery services, especially food delivery. This is used by food and beverage $(F \& B)$ business actors, these business actors collaborate with Go-Jek to develop their business digitally through an agreement previously made by Go-Jek. The problems studied are regarding what legal relationships arise between Go-jek and business actors and how the distribution of rights and obligations of the parties is related to the principle of proportionality. The aim is to examine the legal relationship that exists between Go-jek and $F \& B$ entrepreneurs, and to know the distribution of rights and obligations between Go-jek and F\&B entrepreneurs. The research method used is a research method in the form of a normative juridical research method and a review of statutory regulations Based on the results of the study, it can be concluded that Gojek has determined the contents of the agreement, under the agreement it's done digitally, and can be approved digitally, that after the business actor agrees to the agreement, the business actor automatically becomes a partner, that Go-jek has the right to use the intellectual property rights of business partners regarding appearance, besides that Go-jek has the right to determine SOPs that can be added or reduced from time to time, and business actors have the right to access services and in return pay a profit of $20 \%$ on each transaction that occurs. The legal relationship that arises is a partnership agreement, and that the agreement between Go-jek and business actors does not fully fulfill the principle of proportionality.
\end{abstract}

Keywords: e-commerce, agreements, partnerships, the principle of proportionality.

\title{
I. Pendahuluan
}

Di zaman modern ini dimana teknologi berkembang pesat salah satunya dengan kemunculan teknologi internet, kemunculan internet ini menjadikan komunikasi, interaksi antar manusia semakin mudah dan menjadi lebih efisien dimana waktu dan jarak tidak lagi menjadi halangan, tidak hanya dalam bidang telekomunikasi namun kemunculan internet juga mengubah gaya hidup manusia terutama generasi milenial, didalam bidang bisnis pemanfaatan internet dikenal sebagai Elektronic commerce (e-commerce). E-commerce sendiri adalah proses transaksi dengan menggunakan teknologi internet sebagai media untuk menyebarluaskan produknya, tentu hal ini diharapkan agar kedepannya transaksi jual beli semakin berkembang. (Fahrurrozi, Sayyidi, \& Ali, 2020:147-148). 
Dalam hal ini transaksi jual beli dalam usaha Food and Beverage (selanjutnya disebut sebagai F\&B) menjadi lebih mudah dan efisien serta dapat meminimalisir waktu juga biaya.

Salah satu inovasi bisnis yang muncul dan berkembang adalah Go-jek. Gojek merupakan salah satu platform teknologi terbesar di Asia Tenggara mulai berdiri pada tahun 2010 yang dibuat dan dipopulerkan oleh PT. Go-jek. Dengan layanan pertama adalah pemesanan ojek daring yang dapat dipesan melalui call sentre. Pada tahun 2015 Go-jek semakin berkembang dan memunculkan aplikasi dengan berisi 3 (tiga) layananya berupa go-ride, go-send, dan go-mart, ataupun memesan makanan, ataupun melakukakn pembayaran. (GO-jek, 2020).

Adapun tatacara pendaftaran untuk menjadi mitra gojek dapat dilakukan oleh pemilik usaha dengan melakukan pendaftaran menggunkan aplikasi Go-biz lalu pemilik outlet harus melampirkan datadiri berupa foto KTP pemilik outlet, NPWP, dan fotokopi halaman pertama buku tabungan pemilik "Gojek". Setelah itu pemilik usaha harus menandatangani perjanjian. GoBiz adalah aplikasi dari Gojek yang dibuat khusus untuk para pebisnis di Indonesia. Didalamnya terdapat berbagai fitur mulai dari kelola pesanan GoFood, menerima pembayaran Gopay, laporan penjualan, sampai membuat promo penjualan. Selain itu Gopay merupakan dompet digital yang dimiliki oleh Go-jek. "Gojek" (GO-jek, 2020).

Kehadiran transportasi online salah satunya gojek dengan berbagai fitur dengan salah satunya fitur pesan antar makanan menambah angin segar bagi masyarakat baik costumer maupun pelaku usaha food and beverage (Zuama, Dinda, \& Pamungkas, 2021:4), yang selanjutnya dalam artikel ini disebut sebagai pelaku usaha $\mathrm{F} \& \mathrm{~B}$ adalah pelaku usaha yang bergerak dalam penjualan makanan dan minuman. Maka dari itu pelaku usaha mencari cara bagaimana cara menjalin kerja sama dengan Go-jek agar usahanya semakin berkembang, terutama pelaku usaha yang tidak memiliki layanan delivery, kerjasama sendiri didalamnya berisikan perjajian yang disepakati para pihak. Pengertian perjanjian dalam KUHPer pasal 1313 dijelaskan bahwa perjanjian merupakan suatu kesepakatan antara satu orang atau lebih yang mengikatkan dirinya dengan satu 
orang atau lebih.

Dalam perjanjian akan tercipta suatu hak dan kewajiban bagi para pihak yang berjanji, hak adalah setiap keadaan yang wajib diterima, sedangakan kewajiban adalah segala keadaan yang wajib dilakukan. Kedudukan para pihak dalam perjanjian haruslah ada rasa keadilan yang ukurannya didasarkan pada kepatuhan para pihak dalam memenuhi perjanjian. (Siregar, 2019:2). Perjanjian dapat dikatakan proporsionalitas ketika antara pihak memiliki hak dan kewajiban yang berimbang. Pelaku usaha F\&B memiliki hak untuk mengakses dan melakukan penjualan dengan aplikasi yang disediakan oleh Go-jek, dan memiliki kewajiban untuk memberikan pembayaran atas fasilitas yang diberikan oleh Go-jek. Begitu juga Gojek memiliki hak untuk menerima pembayaran dari pelaku usaha $F \& B$ atas fasilitas yang diberikannya, serta berkewajiban untuk memberikan pelayanan dan fasilitas yang terbaik bagi pelaku usaha F\&B.

Dalam perjanjian menganut suatu asas hukum, yakni asas kebebasan berkontrak, yang menjelaskan mengenani kebebasan seseorang dalam membuat suatu kontrak dengan mencantumkan syarat - syarat, dan perjanjian ini sah selama para pihak menyetujui perjanjian tersebut dan tidak melanggar kesusilaan. Asas kebebasan berkontrak ini tidak diatur usecara jelas baik dalam KUHPer maupun undang undang lainnya. Dalam pasal 1338 ayat (1) KUHPer sendiri di jelaskan bahwa perjanjian mengikat dan menjadi undang - undang bagi pihak-pihak yang menyetujuinya, dapat diartikan bahwa selama para pihak setuju maka perjanjian tersebut haruslah di laksanakan. (Harianto, 2016:149).

Perjanjian yang baik adalah perjanjian yang proporsional dan saling menguntungkan antara para pihak. Dimana para pihak saling diuntungkan atas adanya suatu perjanjian, namun tidak jarang pada zaman modern banyak ditemui perjanjian yang telah disiapkan oleh salah satu pihak, sehingga pihak lainnya tidak bisa mengubah isi dari perjanjian yang telah dipersiapkan tersebut dan hanya dihadapkan pada situasi setuju dan tidak setuju atau tidak bisa tawarmenawar. Adil menurut kamus bahasa Indonesia artinya tidak sewenang wenang, tidak berpihak, tidak berat sebelah. Artinya adil yaitu suatu keputusan dan tindakan yang didasarkan pada norma yang objektif tidak subjektif atau 
sewenang - wenang (Santoso, 2012:85). Adil merupakan suatu perasaan dalam diri seseorang, yang tidak bisa diukur tingkatannya antara satu orang dengan orang lain. Dengan tidak adanya keseimbangan maka akan menimbulkan ketidak adilan.

Maka dari itu para pihak haruslah cermat dalam membaca serta memahami isi perjanjian agar tidak menyesal dilain waktu, untuk mewujudakan rasa adil tersebut maka suatu perjanjian haruslah menjunjung tinggi asas proporsionalitas. Asas proporsionalitas adalah suatu asas yang melihat keseimbangan dengan cara fair bukan dengan cara matematis tapi didasarkan pada mekanisme dan proses pertukaran antara hak serta kewajiban para pihak dengan fair. Aristoteles mengemukakan bahwa prinsip yang sama diperlakukan sama, dan prinsip yang tidak sama juga diperlakukan secara tidak sama. P.S.Atijah merumuskan asas proporsionalitas yang pada intinya dapat dijelaskan bahwa kaitannya dalam peran kontrak sebagai suatu landasan pertukaran yang adil di dunia bisnis, bahwa transaksi serta pembagian hak dan kewajiban antar pihak yang berkontrak sesuai dengan apa yang diinginkan (population in whatthey want). Maka dari itu para pihak tidak mungkin berada pada posisi yang sama, namun dalam kontrak para pihak harus memiliki keadilan yang sama, pihak yang lebih dominan tidak boleh memaksakan kehendaknya kepada pihak lain (Hernoko, 2014:84-87).

Berdasarkan latar belakang tersebut, maka permasalahan yang akan dibahas dalam penelitian ini yaitu:

a. Bagaimana hubungan hukum yang timbul pada perjanjian antara PT. Go-jek Indonesia dengan pelaku usaha $\mathrm{F} \& \mathrm{~B}$ ?

b. Bagaimana pembagian hak dan kewajiban antara PT Go-jek Indonesia dengan pelaku usaha $\mathrm{F} \& \mathrm{~B}$ diakitkan dengan asas proporsionalitas?

Metode penelitian yang digunakan penulis adalah penelitian hukum yuridisnormatif. Karena tujuan dari penulisan ini adalah hukum atau kaidah, dimana dalam metode ini seringkali memandang hanya pada hukum yang tertulis (law in books) atau hukum dijadikan acuan berprilaku manusia yang dianggap baik 
(Amirudin \& Askin, 2010:118), dengan menggunakan pendekatan konseptual (pendapat ahli) dan pendekatan undang-undang (Hernoko, 2014:39), suatu penelitian yang bertuju pada pendapat ahli dalam hal ini mengenai asas proporsionalitas, dan pendekatan peraturan perundang-undangan dalam hal ini di fokuskan pada KUHPer yang berlaku di Indonesia, serta peraturan perundang-undangan lainnya yang berkaitan. Penelitian ini menggunakan bahan hukum primer yaitu berupa peraturan perundang-undangan serta bahan hukum sekunder berupa hasil penelitian dan hasil karya dari kalangan hukum.

\section{Pembahasan}

\section{A. Hubungan hukum yang timbul dalam perjanjian antara PT. GO-JEK Indonesia dengan pelaku usaha $\mathrm{F} \& \mathrm{~B}$}

Hubungan hukum yang timbul merupakan hubungan hukum perjanjian. Perjanjian yang timbul antara PT. Go-jek Indonesia dengan pelaku usaha F\&B adalah perjajian kemitraan, dimana pelaku usaha $F \& B$ secara otomatis menjadi mitra setelah menyetujui perjanjian kerjasama yang telah di tetapkan di awal oleh Go-jek untuk berkerjasama (GO-jek, 2020). Subekti berpendapat mengenai perjanjian yang pada intinya, perjanjian yakni hubungan hukum antara dua orang atau lebih yang didalamnya termuat suatu hak dan kewajiban dimana pihak satu berhak atas suatu hak dan pihak lain wajib melaksanakan kewajibannya. (Hartana, 2016:149).

Syarat sahnya perjanjian di atur pada pasal 1320 KUHPer dapat dijelaskan bahwa agar terjadinya suatu perjanjian yang sah maka harus terpenuhi empat syarat yaitu sepakat, cakap, suatu hal tertentu, dan sebab yang halal.

Unsur sepakat dan cakap termasuk kepada unsur subyektif atau kepada orang yang melakukan perjanjian, jika salah satu atau kedua unsur tersebut tidak terpenuhi, perjanjian dapat dibatalkan. Semisal seorang yang telah dewasa melakukan perjanjian dengan seorang yang belum dewasa maka hal ini tidsak memenuhi unsur subyektif karena salah satunya belum dewasa. Dewasa menurut hukum perdata dijelaskan pada pasal 1330 KUHPer yaitu seorang belum 
dikatakan dewasa apabila belum genap berumur 21 (dua puluh satu) tahun dan belum menikah, namun jika di bawah umur 21 (dua puluh satu) tahun sudah menikah, maka orang tersebut sudah dianggap dewasa dan perjanjian tersebut bisa dibatalkan, sedangkan mengenai hal tertentu dan sebab yang halal termasuk kedalam unsur obyektif atau sesuatu yang diperjanjikan. Namun apabila objek yang diperjanjikan adalah obyek yang melanggar aturan maka perjanjian dapat batal demi hukum.

Kemitraan yang tercantum pada Undang-Undang Nomor 20 Tahun 2008 tentang Usaha Kecil dan Menengah memiliki arti bahwa kemitraan adalah kerjasama anatara perusahaan kecil dengan perusahaan menengah atau dengan perusahaan besaar disertai arahan pembinaan dan pengembangan oleh usaha menengah atau oleh usaha besar dengan memerhatikan prinsip saling memerlukan, saling memperkuat, dan saling menguntungkan.

Kemitraan merupakan kerjasama yang dilakukan dalam bidang usaha baik langsung maupun dan/atau tidak langsung dengan dalih saling memerlukan, mempercayai, memperkuat dan saling memberi untung yang melibatkan pelaku usaha mikro kecil, menengah dan usaha besar. (Susanto, 2015:7).

Perjanjian kontak antara Go-jek dengan calon mitranya dilakukan secara digital dan dibubuhi tanda tangan digial atau klik setuju oleh calon mitanya apabila setuju dengan isi perjanjian yang telah ditetapkan oleh Go-jek. (GO-bizz, 2020). Perjanjian kontak antara Gojek dengan mitra usaha berlangsung selama 2 tahun serta dapat diperpanjang secara otomatis selama satu tahun dan begitu seterusnya, namun dapat dibatalkan oleh pemilik usaha dengan cara mengajukan surat tertulis sebelum 30 hari jatuh tempo kontrak. (GO-jek, 2020).

Berdasar pada Undang-Undang Nomor 19 Tahun 2016 sebagaimana perubahan atas Undang-Undang Nomor 11 Tahun 2008 mengenai informasi dan transaksi elektronik pada pasal 1 angka 17 dijelaskan bahwa kontrak elektronik adalah perjanjian antar pihak yang dibuat melalui sistem elektronik. Pada pasal 5 ayat (1) dijelaskan mengenai informasi elektronik, bahwa Informasi Elektronik, Dokumen Elektronik dan/atau hasil cetakannya termasuk kedalam alat bukti hukum sah. Sedangkan tanda tangan digital dijelaskan pada pasal 11 ayat (1) 
yang dapat dijelaskan bahwa tanda tangan lektronik adalah sah yang pada intinya tanda tangan tersebut harus dilakukakn secara sadar oleh orang tersebut bukan dilakukan oleh orang lain.

Johannes Gunawan menjelaskan bahwa kontrak elektronik yang pada intinya yaitu kontrak buku yang dirancang, dibuat, ditetapkan, serta digandakan, dan disebarluaskan secara digital melalui internet secara sepihak oleh pembuat kontrak (PT. Go-jek) dan ditutup secara digital pula oleh pemutup kontrak (pelaku usaha F\&B calon mitra Gojek). Menurut Edmon Makarim penggunaan istilah kontrak online bagi kontrak elektronik dan mendefinisikan kontrak ini sebagai perikatan atau hubungan hukum yang dilakukan secara elektronik dengan menggunakan jaringan dari system informasi berbasis computer dengan system informasi berdasarkan jaringan dan jasa telekomunikasi yang selanjutnya difasilitasi oleh keberadaan jaringan computer global internet. (Malinda, 2019:34-35).

Dapat disimpulkan bahwasannya kontrak elektronik adalah kontrak yang dilakukan dengan cara digital oleh dua pihak atau lebih dengan gawai ataupun computer sebagai medianya dan tersambung pada jaringan internet, dan bahwa kontrak elektronik ini sah dan berkekuatan hukum sama seperti pada kontrak umumnya yang tertulis atau tertuang dalam kertas, asalkan sesuai berdasar pada pasal 1320 KUHPer.

Perjanjian kemitraan yang dilakukan antara PT. Go-jek dengan pelaku usaha F\&B ini dilakukan secara digital berdasarkann pasal 1 mengenai ketentuan umum. Pada perjanjian kerjasama yang dibuat oleh Go-jek dalam pasal 5 ayat (2) poin 1 yang dapat di artikan bahwa para pihak setuju dan mengerti bahwa perjanjian yang dibuat dalam bentuk kontrak elektronik dan bentuk persetujuan berupa tindakan mengklik pilihan persetujuan secara elektronik sehingga perjanjian ini sah serta mengikat para pihak yang berjanji dan dapat diberlakukan atau di jalankan oleh para pihak. Artinya perjanjian kontarak yang dilakukan antara PT. Go-jek dengan pelaku usaha F\&B calon mitranya dilakukan secara digital dan isi perjanjian tersebut telah ditentukan oleh pihak Go-jek sehingga calon mitra usaha dihadapkan dengan setuju atau tidak setuju 
yang di expresikan baik dalam bentuk klik setuju jika setuju, jangan klik setuju apabila tidak setuju sesuai dengan pasal 2 mengenai hubungan kerjasama. Ataupun tanda tangan secara digital apabila setuju. (GO-jek, 2020). Setelah berhasil mendaftar dan menyetujui segala ketentuan yang sudah dipersiapkan oleh Go-jek secara digital dan disetujui secara digital pula, maka hubungan hukum atara PT. Go-jek dengan pelaku usaha F\&B ini adalah hubungan kemitraan.

\section{B. Pembagian hak dan kewajiban antara PT GO-JEK Indonesia dengan pelaku usaha F\&B dikaitkan dengan asas proporsionalitas}

Dalam suatu kontrak perjanjian yang telah disiapkan terlebih dahulu cenderung akan berisi pernyataan yang secara otomatis menguntungkan pihak yang membuat perjanjian tersebut, sedangkan pihak lainnya dihadapkan pada keadaan setuju dan tidak setuju, dan ini adalah keadaan yang lemah dimana tidak ada tawar menawar antara para pihak dalam menentukan perjanjian tersebut. Dalam setiap hubungan maka haruslah ada pembagian antara hak dan kewajiban begitupula yang terjadi antara hubungan PT. Gojek dengan Pelaku usaha F\&B, dalam setiap transaksi, Gojek mengambil keuntungan sebanyak 20\%. Sebagai contoh A menjual ayam bakar dengan harga perporsi Rp. 20,000,00 maka gojek akan memotong sebanyak Rp. 4,000,00 jadi A akan memperoleh sejumlah Rp. $16,000,00$. Hal ini wajar sebab Gojek telah menyediakan ruang terbuka untuk mitra usaha dalam mempromosikan produknya (GO-bizz, 2020). Pendapatan bersih tersebut akan disetorkan oleh Gojek kepada rekening mitra usaha pada hari berikutnya, sebagai contoh penjualan hari senin sebesar Rp. 20,000,00 maka gojek akan memotong sebanyak Rp. 4,000,00 sehingga A akan mendapat sejumlah Rp. 16,000,00, yang akan Gojek kirim/transfer pada hari esoknya.

Hak dan kewajiban PT. Gojek dengan Pelaku usaha diatur pada ketentuan penggunaan Gobiz tercantum pada pasal 9 mengenai hak dan kewajiban para pihak yang jika dipersingkat yakni bahwa Go-jek berkewajiban menyediakan akses pada pihak mitra usaha yang lolos pendaftaran serta gojek wajib menjaga kerahasiaan data mitra usaha dan wajib menjaga sistem aplikasi agar tetap stabil, 
selain itu gojek memiliki hak untuk menguranggi fitur yang ada pada aplikasi gobiz, menggunakan Hak kekayaan intelektual milik mitra usaha mengenai tampilan, selain itu Go-jek berhak untuk menentukan SOP yang dapat ditambah atau dikurangi dari waktu ke waktu.

Adapun hak dan kewajiban dari mitra usaha adalah berhak untuk mengakses aplikasi gobiz, menerima edukasi dari Go-jek, adapun kewajibannya adalah untuk membayar biaya atas setiap layanan yang digunakan. Selain itu PT. Gojek memiliki kewajiban lain untuk Menerima informasi secara lengkap dan jelas bila timbul kendala pada sistem, baik sistem Go-jek maupun sistem yang digunakan oleh pelaku usaha (GO-bizz, 2020).

Namun Go-jek mencantumkan batasan tanggung jawabnya dalam aturan mengenai ketentuan penggunaan Gobiz seperti yang dijelaskan pada pasal 10 ayat (1) sampai ayat (4) bahwa Go-jek menyatakan tidak beranggunga jawab atas kerugian dan kerusakan, resiko-resiko lain yang timbul atau yang mungkin timbul dari penggunaan gobiz ini, dan semuanya itu menjadi tanggung jawab dari mitra usaha. (GO-bizz, 2020).

Terlepas dari hak dan kewajiban antara PT. Gojek dengan Pelaku usaha, Gojek juga memberikan kompensasi dan tanggung jawabnya kepada pelaku usaha bahwa Gojek menyatakan akan memberikan konpensasi apabila mitra usaha telah menerima dan menyiapkan pesanan namun Gojek tidak dapat menyediakan mitra driver-nya yang akan melakukan pengantaran pesanan kepada konsumen (tidak diketahui jelas berapa besaran ganti kompensasinya) (GO-bizz, 2020). Bahwa dengan Go-jek mengambil keuntungan sebanyak $20 \%$ dari setiap transaksi yang terjadi dengan pelayanan dan fasilitas yang diberikan, juga memberikan kompensasi pada keadaan tertentu kepada mitra usahanya.

Asas proporsionalitas sendiri adalah asas yang menjadi dasar atas pertukaran antara hak dan kewajiban antar pihak sesuai porsinya dan kemampuannya dalam seluruh proses kontraktual. (Hernoko, 2014:87) Maka dari itu suatu perjajian/kontrak dikatakan memenuhi asas proporsionalitas apabila: 
1. Kontrak yang mengakui adanya hak, peluang serta kesempatan yang sama (kesetaraan hak) kepada para pihak untuk menentukan pembagian yang adil bagi mereka

2. Kontrak yang dilandasi dengan kebebasan antar pihak untuk menentukan isi atau apa yang akan dituangakan dalam kontrak mengeni seberapa adil dan apa yang tidak adil bagi mereka

3. Kontrak tersebut mampu memberi jaminan pelaksanaan hak dan kewajiban secara proporsional antara para pihak (bukan berati harus mendapatkan bagian yang sama namun di kembalikan kepada pembagian yang adil sesuai porsinya)

4. Dalam hal apabila timbul sengketa perjanjian, maka beban dari penanganan pembuktian, berat ringannya suatu kesalahan maupun hal-hal lainnya yang terkait, harus dilihat berdasarkan asas proporsionalitas untuk memperoleh hasil yang terbaik serta penyelesaian yang elegan dan win-win solution (Hernoko, 2014:88-89).

Apabila dilihat dari syarat kontrak memenuhi asas proporsionalitas maka kontrak antara Gojek dengan Pelaku usaha ini sebagian telah memenuhi syarat tersebut, namun sebagiannya belum terpenuhi sebagai contoh pada ketentuan yang menyatakan mengenai pertukaran yang adil, tentu ini tidak dilakukan dalam kontrak antara Gojek dengan mitra usaha sebab isi perjanjian telah dibuat dan tidak bisa diubah.

\section{Penutup}

\section{A. Kesimpulan}

1. Antara PT. Go-jek dengan pelaku usaha F\&B terjalin hubungan kemitraan setelah pelaku usaha menyetujui perjanjian yang dibuat oleh Go-jek, Kemitraan sendiri adalah kerjasama yang dilakukan dalam bidang usaha secara langsung maupun tidak secara langsung dengan dasar saling memerlukan, mempercayai, memperkuat dan saling menguntungkan yang melibatkan pelaku usaha mikro kecil dan 
menengah dengan usaha besar, dalam melakukan perjanjian kemitraan Gojek dengan pelaku usaha F\&B dilakukan dengan cara digital / kontrak digital yang dilakukan dengan media smartphone / computer dengan tersambung pada jaringan internet, dan perjanjian secara digital ini adalah sah selama tidak bertentangan dengna Undang-undang seperti yang tercantum dalam Undang-undang No. 19 Tahun 2016.

2. Gojek dalam setiap transaksi mengambil keuntungan sebesar $20 \%$. Bahwa Gojek dan mitra usahanya wajib mentaati Undang-undang yang berlaku di indonesia serta saling menjaga citra dan nama baik para pihak. Hak dan kewajiban mitra usaha adalah bahwa mitra usaha berhak mengakses secara penuh aplikasi Gobiz dan mempergunakannya, mitra usaha berhak menerima edukasi dari gojek mengenai penggunaan aplikasi, serta mitra usaha memiliki tanggung jawab penuh atas segala yang dilakukannya dan menjaga rahasia informasi yang diberikan oleh pihak aplikator. Hak dan kewajiban Gojek. Bahwa aplikator wajib menyediakan akses kepada pelaku usaha yang lolos sleksi dan menjaga kerahasiaan data informasi mitra pelaku usaha, serta wajib menjaga sistem aplikasi dengan baik, pelaku usaha memiliki tanggung jawab penuh atas kerugian dan permasalahan yang timbul dari penggunaan gobiz. layanan penawaran pembayaran. Gojek menyatakan lepas tangan dari segala permasalahan yang terjadi namun Gojek memberikan kompensasisemisal Gojek tidak dapat menghadirkan mitra driver untuk mengambil pesanan yang telah dibuatkan oleh mitra usaha, maka gojek akan memberikan kompensasi yang tidak diketahui pasti besarannya. Kontrak yang memenuhi asas proporsionalitas adalah yang berisikan antara hak dan kewajibanyang berkeseimbangan serta memberikan kesempatan dan peluang yang sama, dilandasi kebebasan para pihak untuk menentukan substansi, kontrak yang dapat menjamin pelaksanaan hak dan kewajiban, kontrak yang berisikan penyelesaian sengketa. 


\section{B. Saran}

1. Diharapkan kedepannya agar perjanjain PT. Gojek dengan pelaku usaha F\&B semakin lebih baik, serta kontrak digital yang telah disiapkan dapat diubah dengan cara membuat opsi singkat, sehingga calon mitra dapat palingtidak mengungkapkan keinginannya yang diharapkan masuk kedalam kontrak perjanjian tersebut.

2. PT. Gojek Indonesia dapat mengakomodir permasalahan lainnya semisal layanan aplikasi bermasalah sehingga merugikan pelaku usaha maka Gojek harus bertanggung jawab, kecuali dan keadaan yang tidak bisa di prediksi, serta tidak melepas tanggung jawab begitu saja apabila mitra usaha mengalami permasalahan baik hukum maupun dalam pengelolaan, paling tidak Gojek wajib menyediakan pendampingan terhadap mitranya.

\section{Daftar Pustaka}

Amirudin, \& Askin, H. Z. (2010). Pengantar Metode Penelitian Hukum. Jakarta: PT Raja Grapindo Persada.

Fahrurrozi, Sayyidi, \& Ali, I. (2020). Analisis layanan ojek online PT. Grab Indonesia wilayah Surabaya dalam perspektif bisnis islam. Jurnal ekonomoi \& ekonomi syariah, 3(1). https://doi.org/10.36778/ jesya.v3i1.139

GO-bizz. (2020). Persyaratan GO-FOOD dan cara Daftar Gobiz 2020, Berapa Biaya Daftar atau Bagi Hasil Gofood?, Ketentuan Penggunaan Gobiz. Diambil 20 November 2020, dari GO-bizz website: https://www.gobizz.com/search/label/GOFOOD

GO-jek. (2020). Tentang Gofood, Jualan Aman dan Nyaman Hanya Dalam Satu Genggaman, Syarat dan Ketentuan Gofood (Gobiz). Diambil 6 November 2020, dari GO-jek website: https://www.gojek.com/

Harianto, D. (2016). Asas Kebebasan Berkontrak: Problematika Penerapannya Dalam Kontrak Baku Antara Konsumen Dengan Pelaku Usaha. Jurnal 
Hukum Samudra Keadilan, 11(2). Diambil dari https://ejurnalunsam.id/index.php/jhsk/article/view/33

Hartana. (2016). Hukum Perjanjian Dalam Perspektif Perjanjian Karya Pengusahaan Pertambangan Batubara. Jurnal Komunikasi Hukum, 2(2). https://doi.org/10.23887/jkh.v2i2.8411

Hernoko, A. Y. (2014). HUKUM PERJANJIAN Asas Proporsionanlitas Dalam Kontrak Komersil. Jakarta: Kencana.

Malinda, D. (2019). E-contract pada PT. Go-jek Indonesia Dalam Perjanjian Dengan Mitra Usahanya Menurut Syirkah'inan. Universitas Islam Negri An-Raniry Darusalam Banda Aceh.

Republik Indonesia. Kitab Undang-Undang Hukum Perdata (KUH Perdata).

Republik Indonesia. Undang-Undang Nomor 19 Tahun 2016 Tentang Informasi dan Transaksi Elektronik.

Republik Indonesia. Undang-Undang Nomor 20 Tahun 2008 Tentang Usaha Mikro, Kecil dan Menengah.

Santoso, A. (2012). HUKUM MORAL \& KEADILAN Sebuh Kajian Filsafat Hukum. Jakarta: Kencana.

Siregar, A. M. (2019). Perjanjian Kredit Antara Bank Dengan Pelaku Usaha Kecil dan Menengah Dalam Meningkatkan Perekonomian Masyarakat. Reformasi Hukum, 23(1). https://doi.org/10.46257/jrh.v23i1.58

Susanto, D. A. (2015). Penerapan Asas Proporsionalitas Dalam Kemitraan Pada Perjanjian Kerjasama Antara Koperasi Produsen Mekar Jaya Dengan PT. Tani Musi Persada. Universitas Islam Indonesia Yogyakarta.

Zuama, A. P. C., Dinda, C. M., \& Pamungkas, D. (2021). Telaah Regulasi Ojek Online di Indonesia dalam Persfektif Filsafat Fenomenologi Hukum. Reformasi Hukum, XXV(1). https://doi.org/10.46257/jrh.v25i1.182 